
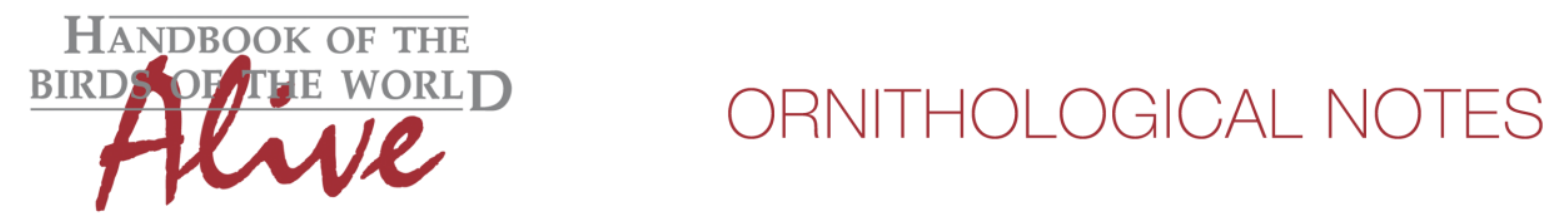

\title{
Notes on the vocalizations of Pale-legged Hornero (Furnarius leucopus)
}

Peter Boesman

In the following we briefly analyze and compare voice of the different races of Pale-legged Hornero (Furnarius leucopus). We also try to quantify the extent of any vocal differences using the criteria proposed by Tobias et al. (2010), as a support for taxonomic review.

We have made use of sound recordings available on-line from Xeno Canto (XC) and Macaulay Library (ML).

A potential split of this complex into 3 species has been discussed in http://www.museum.Isu.edu/ Remsen/SACCprop35.htm

From the discussion it is clear that while 'vocal differences' have been claimed in several field guides and elsewhere, few mention what these vocal differences are, let alone how different they are when quantified.

After having listened to recordings from all races, it seems to me that the loudsong is generally similar, a loud fairly long series of staccato notes which descend in pitch and decelerate at first and then stay at the same pitch and pace. There is thus not a race which stands apart by a 'very different song'.

There is quite some variation within all races, probably depending on the level of excitement of the bird. Also, two birds often sing in asynchronous duet, and deliver somewhat different songs.

Making abstraction of these variations, and choosing recordings of what looks like 'typical songs of birds which are not too excited', we found the following:

\section{Caribbean Hornero group (F. I. longirostris)}

\section{Typical song:}

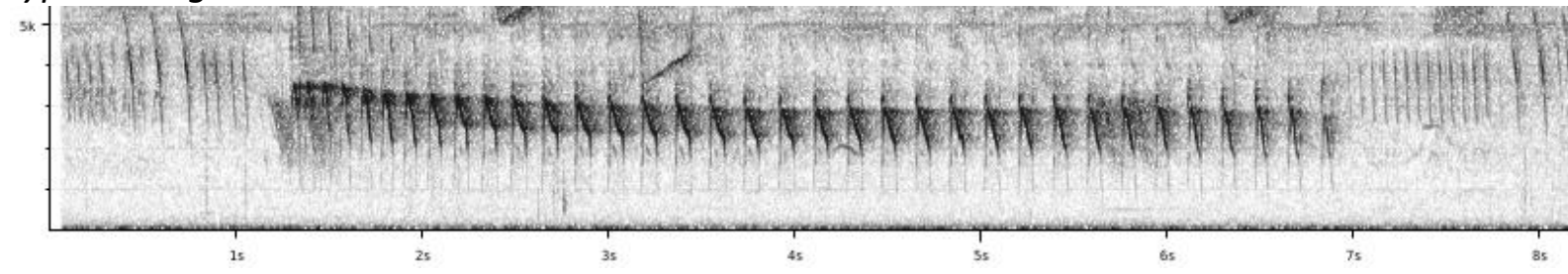

Measurements:

Note length in stable part of song:

Max. freq. first notes

Max. freq. notes in stable part

Pace of first notes (first 5 taken)

Pace of notes in stable part (5 notes)

Deceleration

Ratio note length/pause length

Note shape

Total length of song
$0.085-0.1 \mathrm{~s}$

$3450-3650 \mathrm{~Hz}$

$2750-3000 \mathrm{~Hz}$

0.43-0.58

0.75-1.08

$30-140 \%$

0.7-0.9

Unique among all races, every note has at first a sharp peak and a downslurred part

$5-8 \mathrm{~s}$ 

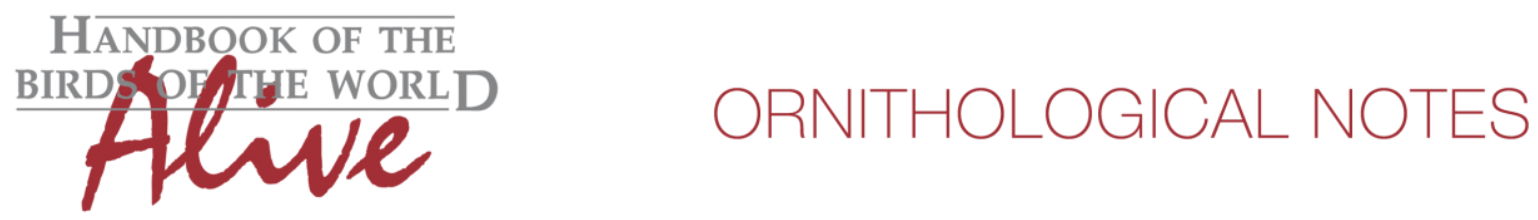

\section{Pale-legged Hornero group - $\mathrm{N}$ of Amazon (F. I. leucopus)}

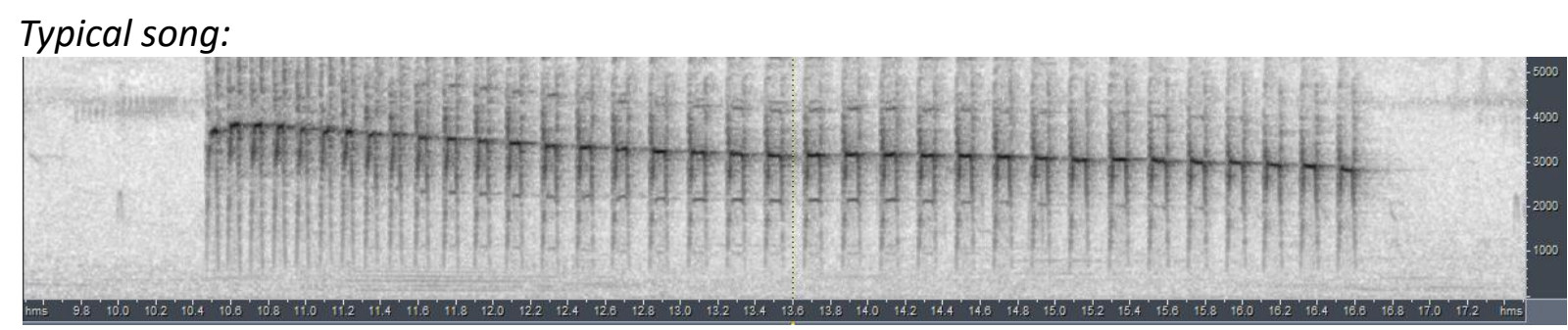

Measurements:

Note length in stable part of song:

Max. freq. first notes

Max. freq. notes in stable part

Pace of first notes (first 5 taken)

Pace of notes in stable part (5 notes)

Deceleration

Ratio note length/pause length

Note shape

Total length of song

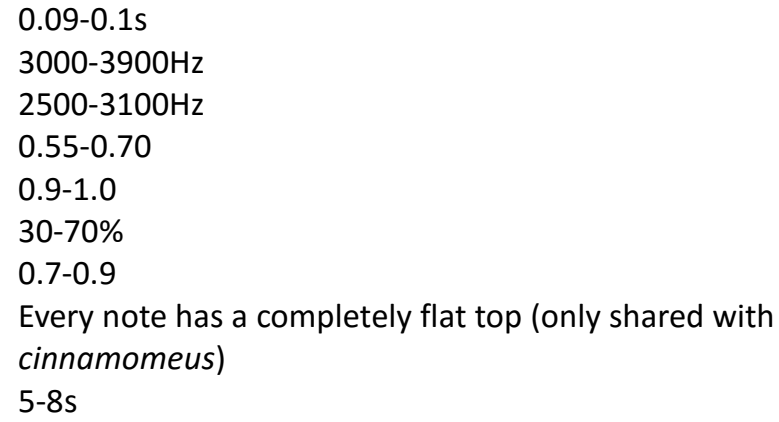

\section{Pale-legged Hornero group - S of Amazon (F. I. tricolor, F. I. araguaiae, F. I. assimilis)}

\section{Typical song:}

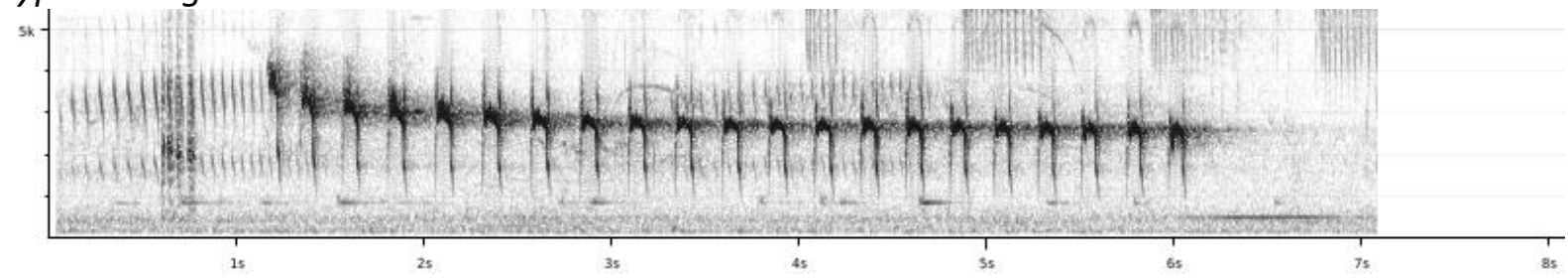

Measurements:

Note length in stable part of song: Max. freq. first notes

Max. freq. notes in stable part Pace of first notes (first 5 taken) Pace of notes in stable part (5 notes) Deceleration

Ratio note length/pause length Note shape

Total length of song
$0.075-0.13 \mathrm{~s}$

$2800-4000 \mathrm{~Hz}$

$2300-2900 \mathrm{~Hz}$

0.7-1.18

$0.9-1.36$

$12-70 \%$

$0.5-1.0$

Unique compared to other groups, every note has a burry top of several 'oscillations' and with an initial spike 4-6.7s 

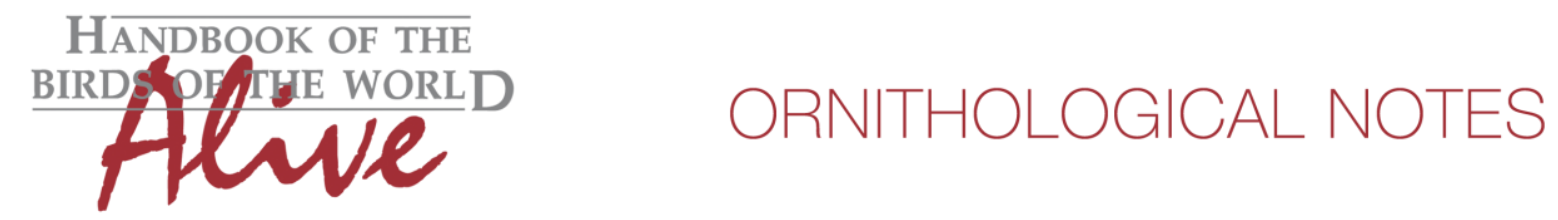

Pacific Hornero group (F. I. cinnamomeus)

Typical song:

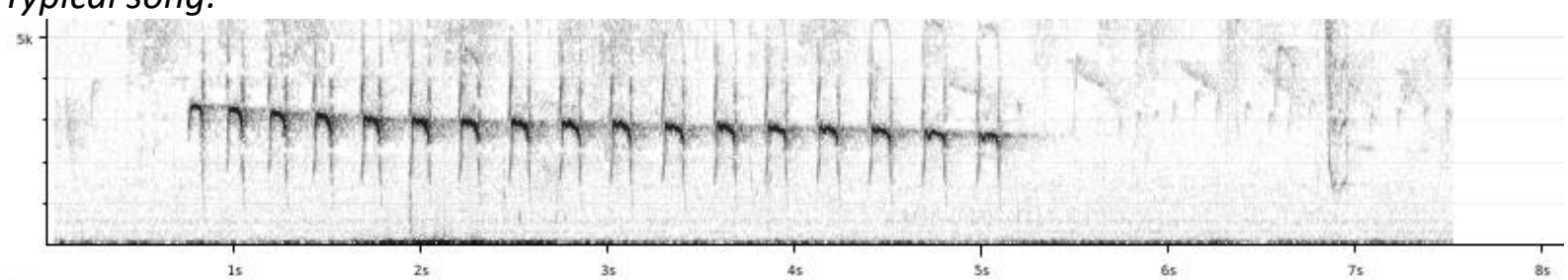

Measurements:

Note length in stable part of song:

$0.1-0.11 \mathrm{~s}$

Max. freq. first notes

$3200-3300 \mathrm{~Hz}$

Max. freq. notes in stable part

$2700-2900 \mathrm{~Hz}$

Pace of first notes (first 5 taken)

0.86-1.0

Pace of notes in stable part (5 notes)

$1.0-1.2$

Deceleration

$15-20 \%$

Ratio note length/pause length

0.65-0.75

Note shape

Every note has a completely flat top (only shared with

Total length of song leucopus)

$4-6 s$

From comparison of the above date, note shape seems to be the principal distinguishing feature, other basic parameters show certain differences but effect size is rather small. Note shape can be quantified by e.g. defining parameters like 'frequency range between 0.20.8 of note length', 'number of changes in slope from rising to falling per note' etc. and would lead to ranges not overlapping between 3 groups, although obviously it is debatable whether scoring into such detail is applicable.

\section{Conclusion:}

It would thus seem that vocal differences are less striking than typically assumed.

Caribbean Hornero versus all others:

Unique among all races, every note has at first a sharp peak followed by a downslurred part (score 3, at most!), and song has largest deceleration with first notes shortest in length (score 1). This would lead to a total vocal score of at most 4 when applying Tobias criteria.

Pale-legged Hornero south of Amazon versus all others:

Unique compared to other groups, every note has a burry top of several 'oscillations' and with an initial spike (score 3 , at most!)

Pacific Hornero versus Caribbean and Pale-legged Hornero $\mathrm{S}$ of Amazon

Note shape has a flat top (score 3, at most!) and song has by far smallest deceleration (score 1-2). This would lead to a total score of about 4.

Pacific Hornero vs. Pale-legged Hornero N of Amazon

Song has smallest deceleration (score 2, more than previous as ranges are more divergent) 
This note was finalized on 10th April 2015, using sound recordings available on-line at that moment. We would like to thank in particular the many sound recordists who placed their recordings for this species on XC and $\mathrm{ML}$.

\section{References}

Tobias, J.A., Seddon, N., Spottiswoode, C.N., Pilgrim, J.D., Fishpool, L.D.C. \& Collar, N.J. (2010). Quantitative criteria for species delimitation. Ibis 152(4): 724-746.

\section{Recommended citation}

Boesman, P. (2016). Notes on the vocalizations of Pale-legged Hornero (Furnarius leucopus). HBW Alive Ornithological Note 88. In: Handbook of the Birds of the World Alive. Lynx Edicions, Barcelona. (retrieved from http://www.hbw.com/node/931982 on 18 July 2016). 